\title{
The Surveillance of Cellular Scientists' Practice
}

\author{
Jamie Lewis and Paul Atkinson \\ Published in BioSocieties
}

\begin{abstract}
We discuss a set of practices surrounding the creation of Good Manufacturing Practice (GMP) performed within a cell laboratory. This process exemplifies a wider imperative to render visible the work of laboratory science. The creation of visibly accountable practices in turn reflects and reinforces the wider trend towards standardisation of cell practice. Standards themselves have thus become some of the artefacts created in laboratories, biobanks and other sites of biomedical work. Such processes of visibility and accountability translate the local, craft practices of laboratory work - often tacitly performed and transmitted - into explicit forms of knowledge production and regulation. Where once, however, laboratory work depended to a large degree on trust, newer modes of regulation impose new layers of mutual surveillance. Visibility is enhanced through technologies of inspection and surveillance, by increased volumes of self-documentation, and by the imposition of regulatory protocols. Together these transform what was once implicit in the working practices of trusted professionals into explicitly accountable practices. Therefore the achievement of GMP accreditation is one example of the current imperative towards reflexive-accountability where new trans(national) monitoring technologies create new regimes of surveillance in biomedical science.
\end{abstract}




\section{Biomedical science, regulation and visibility}

Biomedical science is developing at an accelerating pace. Advances in genomics, stem cell therapy and nanotechnology promise to change the scientific landscape as we know it. Promise is so dramatic that such life-changing and life-defining ventures are deliberated in politically charged environments where debates are ongoing surrounding their potential social implications (Franklin 2001; Kater 2007). Central to these debates are ethical and legal issues surrounding the conduct of research. It is predicted that such technologies will lead to groundbreaking innovations in medicine, human enhancement, and biological understanding, potentially changing our perceptions of what it is to be human (Haraway 1991) and what it is to be healthy (Finkler 2000). It would appear then that the work of scientists is being scrutinised like never before. Fears of dystopian futures are evident, and yet are counterbalanced by biological utopian visions of a healthier population (Hindmarsh 2008). Each scientific breakthrough is designated by the media as either Frankenstein or Miraculous science. Monster or miracle, these grand terms suggest that we are on the threshold of a new scientific age complicated by public concerns that are redefining the scale, scope and boundaries of biomedical practice (Brown and Webster 2004).

Evelyn Fox Keller maintains that $20^{\text {th }}$ century science will be remembered as the century of the gene (Keller 2000). The gene is one example of a previously invisible entity, made visible through developments in new technologies: visible in the sense of being detectable, representable and describable. Indeed, it was the mapping of the genome at the very end of the century that has arguably changed the way biological 
practice is conducted. Developments in biomedical platforms, communication networks and high-throughput technologies have meant that bioscience is now 'big' (da Solla Price 1965; Bartlett \& Arribas-Ayllon 2009): organisationally big, geographically big and big in terms of its aspiration and impact. Part of this bigness, can be placed within the context of international collaborations. International science with wide social implications entails national and trans-national regulation. The regulation of biomedical science is then increasingly enshrined in trans-national organisations, standards and legal frameworks. These in turn depend upon technologies of surveillance, measurement and monitoring, and it is these practices of accountability that make scientific work itself a visible outcome of laboratory work.

In much the same way that technologies render visible the objects of scientific work, in this paper we demonstrate the ways in which the methods of scientific practice are rendered visible too. This has become apparent because monitoring practices have made previous invisible aspects of the laboratory environment - such as air pressure visible and potentially controllable. We demonstrate this increased visibility by paying particular attention to the processes of surveillance and traceability, and by commenting on the difference surveillance makes to the actions of scientists. We also describe the ways in which heightened scrutiny shapes new categories and subjects, making scientists themselves more visibly accountable. This is a transformation in the culture of scientific practice (Franklin 1995).

\section{Visual Culture of the Laboratory}


The enhanced visibility of laboratory practice extends the visual culture of the laboratory. As a number of authors have noted, visual evidence is deeply embedded in the history and culture of scientific practice (cf. Crary 1990; Galison 1997). The production and circulation of images and visual representations is central to the regimes of credibility and evidentiality of scientific work (Lynch 1985, 1990). In recent years, the visual culture of biomedical work has been thoroughly explored, for instance in Dumit's analysis of Positron Emission Tomography (PET) brain imaging (Dumit 2004) or Saunders's ethnography of the diagnostic interpretation of Computerised Tomography (CT) images (Saunders 2008). Techniques of visualisation provide vivid representations of biomedical phenomena such as organs, lesions, and brain-function. They furnish an especially persuasive array of representations and add an evidential base to biomedical and clinical interventions. For example, new biomedical technologies make visible biological entities such as genes and stem cells, and create representations of otherwise invisible processes such as brain function (van Dijck 2005; Dumit 2004).

Our own analysis of the visibility of laboratory practice extends the treatment of visual culture by exploring the visualisation of laboratory process itself. Visual culture is, therefore, implicated in the cultures of scientific work and in the audit culture of contemporary regulatory regimes. The management of new biomedical technologies makes visible the practices that create and use such entities and procedures. These include practices of quality assurance, the curation of cell lines, and the creation of 'cultures of surveillance' that render such practices accountable. The creation of visibly accountable practices in turn reflects and reinforces the wider trend towards standardisation of practice. In other words, standards are themselves among the artefacts 
created in laboratories, biobanks and other sites of biomedical work. Visibility supports explication, and underwrites its credibility. Our discussion therefore parallels that of Strathern (2000a) who has commented on the 'tyranny of transparency' occasioned by cultures of accountability and audit in scholarly and scientific research. She explores the contemporary cultures of visibility on the academy, arguing that the imperative is to render things visible (cf.Tsoukas 1997). Our analysis of the visibility of scientific work here therefore affirms the extended extent of visualisation, through practices of surveillance, which render scientific sites and their outcomes increasingly accountable. Our account of extended visibility is intended to capture the extent to which 'visualisation' is to be understood literally (through techniques of surveillance) and metaphorically (through processes of accountability).

\section{Good Manufacturing Practice and Headlab}

Our analysis of tissue surveillance is based on a fifteen-month period of ethnographic fieldwork (Oct 2008- Jan 2010) at a laboratory researching into Huntington's Disease (HD), hereon referred to as Headlab. The Headlab researchers are working towards cell transplantation trials for HD patients. Specifically, they intend to transplant embryonic striatal cell grafts 'obtained from elective terminations of pregnancy' into early onset patients. It is hoped that this experimental procedure will help alleviate a condition that has no effective pharmaceutical or surgical treatments. It is also anticipated that this treatment will be proof of principle for stem-cell therapies for HD. 
Initial trials began in 2000/01. In 2004, however, new European Union (EU) directives concerned with the storage and manipulation of cellular tissue ${ }^{1}$ meant Headlab had to suspend those trials. From this date onwards Headlab maintain a Good Manufacturing Practice (GMP) license was required in order to proceed with the trial. Of course, EU regulation requires local interpretation by the laboratories in question. We are therefore not arguing that this is the only interpretation of the directive. Rather, we are pointing to the particular context in which Headlab positions the directive. On this Professor Evans:

'The EU introduced in - I guess it was 2003/04 - what was known as the Cells and Tissues Directive which said effectively that any cellular or biological product to be used in patients for treatment or for research, whether it was commercial or pilot studies, had to be handled, distributed, stored, labeled, according to so called GMP standards which is a pharmaceutical grade set of conditions for demonstrating protection for - of the cells themselves.'

A GMP license requires the construction of a suitably graded and accredited GMP facility to process the material, and the creation of clear, coherent standard operating procedures (SOPs). The site of such GMP facilities has been the focus of previous work conducted by Stephens, Atkinson \& Glasner (2008) at the UK Stem Cell Bank. Building on the work of Thrift (2006) they describe the 'performative architecture' of such spaces: how access to the laboratories purpose-built building involves the use of swipe cards, passing through air locked doors and a ritualized gowning-up procedure. They also

\footnotetext{
${ }^{1}$ At the time of fieldwork, the storage and licensing of tissue in the UK is said to come under the regulatory jurisdiction of the Human Tissue Authority. The current Authors however demonstrate how current regulation of such practices is in flux.
} 
demonstrate the visible, ceremonial procedures scientists perform in order to enact sterility, safety and hygiene. In this paper we explore the impact that GMP technologies and SOPs - in particular increased physical scrutiny - has on the accountabilities, the categories and the relationships of the cellular scientists involved. This is developed through an account of the creation of Headlab's GMP space ${ }^{2}$.

Good Manufacturing Practice (GMP) has over 80 years of history. Introduced with the Therapeutic Substances Act of 1925, it was initially created in order to control for substances that could not be tested adequately by direct chemical means (Applebe 2005). Today, GMP is part of the Quality Assurance checks which ensure that products are consistently produced and contained in accordance with registered standards. In recent years, with the adoption of EU regulation (Directive 2004/23/EC), this approach to medicinal products has extended to Human Tissue products under the Human Tissues Act of 2004. In the United Kingdom this has come under the auspices of the Medicines and Healthcare products Regulatory Agency (MHRA) and, latterly, the Human Tissue Authority (HTA). Of course, in so far as there are many standard procedures of compliance in cellular laboratories, we do not argue that GMP is the best or the gold standard. Indeed, the very nature of GMP at Headlab is that it is simultaneously prescribed through (trans-)national regulation and enacted through local laboratory practice as Headlab scientists endeavour to follow guidelines concerned with production and quality control in order to keep tissue 'sterile' and free from contamination. The implementation of GMP is then just one instance of a more generic turn to the regulatory culture governing scientific practice.

\footnotetext{
${ }^{2}$ At the time of fieldwork, although most of GMP facility was built, Headlab had still not been given the green light to continue the trials because they were still working on the suite's air ventilation system.
} 
Earlier Headlab trials were conducted in Category Two and Three safety cabinets, extremely clean environments but not to the same level of quality control as required by GMP. For example, although the previous non-GMP trials were conscientiously selfregulated, they did not involve the construction of a purpose-built facility or the inspection and documentation of all the actions therein. The new GMP climate has seen Headlab build a suite inside their laboratory similar to the UK Stem Cell Bank (cf. Stephens et al.2008) containing three adjoining rooms. A description of this facility is important. The first room is categorized as a semi-clean room where those accredited to enter the suite will change out of their casual clothes and into a first level of clothing their 'scrubs'. From that room they move into a smaller changing room where members will gown up into completely sterile GMP accredited 'Tyvek suits' colloquially known as 'bunny suits', which include gloves, boots and hoods. Finally there is the third inner room; the official clean room containing a Category Two 'hood' - the highest grade of the whole suite. Personnel enter the room from the right maneuvering through the two previous inter-locking doors and as they travel inwards the pressure gradient across the rooms increases by 15 Pascals, with the inner room running at 45 Pascals above the ambient of the rest of the laboratory - the highest pressure. While Headlab members will enter from the right, the tissue enters through a transfer hatch from the left and is handled by fully-suited members at the hood. Cameras are positioned directly at the site of dissection and ID cards have to be swiped to enter the farthest right room. Barometers record and regulate the air pressure inside the rooms and thermometers measure the temperature. The whole process will also be intensively chronicled and those documents safely stored (cf. Wilson-Kovacs, Weber \& Hauskeller 2010). 
It is clear from the description of the GMP suite that the regulation of tissue use is overseen by surveillance technologies that are used to vigilantly inspect whether scientists align with current EU standards. Computers and other technologies are gradually altering the nature of surveillance by routinizing, broadening and deepening scientific actions (Lyon 2007). However, the ritualised maintenance of sterility in the laboratory setting is by no means unique to Headlab, nor to GMP requirements. It is characteristic of a great many settings - scientific, clinical and industrial. Indeed, we draw attention to it here in order to stress not merely its immediate function but to suggest that it is part of a generic cultural and behavioural Gestalt. It entails one set of performances that render sterility visible and thus elicits a performative display on the part of lab personnel. Such displays mean that scientists' and technicians' actions can be monitored, measured, and evaluated. Their movements and actions can, therefore, be calibrated against internationally-prescribed standards. The small, daily rituals of the laboratory can be used to enrol the laboratory workers into wider patterns of prescription and surveillance. We address each regulatory technology that is used to monitor practice at the laboratory before summarising our findings in the conclusion.

\section{Headlab and Surveillance Architecture}

We begin by describing the ritual [Author 1] had to routinely perform to enter the laboratory. Headlab is based in a university building which it shares with other similartype laboratories. It is positioned on the third floor and to enter the building researchers require access to an activated security card: 
"To enter the laboratory, I was given a security card. In order to access the laboratory I positioned the card in front of a black mechanism affixed against the main door. A red light turned green, signifying that the door was no longer locked and I was permitted to enter. The opened door gave access to the building and its flight of stairs. After walking upstairs to the appropriate floor, I then followed a similar card routine in order to enter Headlab's main laboratory space. This was the first day of fieldwork, and standing in front of the building, security card in hand, waiting to perform this procedure was the first signal that the building was 'exclusive'; restricted in the sense that certain actors were privileged to obtain a keycard that would permit them to enter a space. I was permitted to enter the building and the laboratory; while non-card others were restricted access.” (Field Notes 13/02/08)

One of the functions of surveillance within scientific architecture therefore is to privilege a select few over others. By establishing physical boundaries that cordon off qualified scientific experts from the lay public it makes certain actors legitimate, while simultaneously making others illegitimate.

The same architectural performativity is true of the GMP facility that has been built within Headlab's perimeter. The extract below reveals how the sense of admittance and acceptance Author 1 felt when given the keycard was taken away from him when he requested access to the GMP suite:

"I had arranged to meet Dr. Leonard at the meeting desk; the frontstage of the lab's quarters. This is where the group met any visitors. She was to take me down to the basement and to the animal house to observe some experiments. While walking towards the elevator we moved closer to the GMP facility, I asked Dr. Leonard whether I could 
have a peek into the room. She replied stating that she would happily show me the outside (which she did), but I was not allowed inside since I did not have the appropriate GMP training. I asked whether she was GMP accredited. She told me she was and, that when the time came, she will be using the facility for her work. The elevator pinged; we stepped inside and went down to the basement". (Field Notes 21/02/08)

Despite the obvious ethical issues surrounding animal experimentation, Author 1 was allowed entry to the animal house when accompanied by the properly accredited person $^{3}$. He was, however, completely restricted from entering the GMP facility. Although he was never invited to participate in scientific practices ${ }^{4}$, as far as he was aware, this was the only space that he was not sanctioned to enter. Thus, despite the keycard presented to him at the beginning of the fieldwork transforming him from a public outsider into an accredited insider, it was at this juncture that it became observably apparent he was a non-expert given special dispensation to enter the main laboratory spaces, but that this did not include the GMP area.

When up and running, the facility will create a similar social divide within Headlab. Only those researchers trained to the appropriate GMP standard will be permitted access to the facility and only after following a prescribed gowning ritual (Stephens et al. 2008). Other Headlab members who had previously been given free reign of their laboratory will not be permitted to enter the newly designed quarter. Thus the GMP facility is a prioritised place: it is a place that sequesters clean and safe legitimate practice and researchers from other unsafe and unregulated laboratory members. Faulkner

\footnotetext{
${ }^{3}$ Author 1 did have to pass a routine health check, before being permitted to enter the animal house.

${ }^{4}$ Penders (2008) tells us how, when studying scientists researching into nutrigenomics, he was encouraged to participate in experiments.
} 
et al. (2006) maintain that the societal perception of contamination is frequently accompanied by a regulatory response in the form of partitioning. To this end, it might be argued that a socio-scientific response to working with cellular products has been to quarantine such actions.

This then represents a further sifting processing other than that which separates the scientists from the general public, but one which actually divides the laboratory members into orders of specifically trained research staff and untrained researchers. This is a significant change to the dynamics of the group and to what was accepted practice before. Novel types of work practices, new forms of speciality and fresh modes of legitimation therefore result from heightened regulatory constraints.

As we write this article, the GMP space has been over two years in the making. The written SOPs that will be integrated into the practice will not only restrict access for some laboratory members, but will also prevent the University's Security department, the University's Estates department and the Fire service from entering the space without permission. On this, Dr. Cowan:

"It means that there is no access for security or estates or anybody else. None of them have access. They will have to go through us to get into that room... They usually have access to most places, but we cannot have that happen...Actually in the event of a fire alarm, our doors will actually fail locked and not fail open...we can't risk that if someone trips the alarm just for burning toast that if all those doors fail open and someone goes in there, the tissue's compromised." 
When fully functioning, the Security and Estates departments will not be able to enter the space without special dispensation. Thus, in one social world the facility will produce new types of hierarchies within the laboratory restricting certain researchers' liberties, while in another it will alter localised day-to-day university practices, changing the ways in which Estates and Security operate within this laboratory. With the introduction of GMP what we have described here then is a monitoring technology whereby the physical partition creates new divisive categories that lead to a change in working practices. The condition of the tissue is prioritised over existing university practices demonstrating its cultural significance. Against this background the institutional dynamics within the laboratory and between wider university associates change as some actors are positioned in the 'in' group and others are placed in the 'out' group ${ }^{5}$ who require permission from the 'in' group to enter.

\section{The Daily Scrutiny}

New technologies of surveillance can transform the nature of scientific work and laboratory practice. The scientist - irrespective of such personal qualities as competence and integrity - is potentially a dangerous actor within the field of regulatory surveillance. He or she is a potential source of dangerous contamination, and must therefore be hedged around with ceremonial observances and symbolic boundaries. These observances are reminiscent of those boundary-marking ceremonials noted by Douglas (1966), which control matter that is symbolically out-of-place. In the management of stem-cell science, the potential for contamination is, of course, practical rather than a purely symbolic infraction of classificatory systems. The daily enactment of visible purity is an

\footnotetext{
${ }^{5}$ Despite being an accredited insider, Author 1 was positioned in the out group.
} 
intensification of regimes of periodic visitations and sporadic inspections. This transformation has meant that with the introduction of GMP, scientists at Headlab will have to execute a daily performance of best practice care, sterility and duty. This therefore changes the work practices of individuals as they are expected to perform in a programmatic, thorough manner. As is described by Dr. Leonard, cameras positioned directly at the dissection process are a permanent reminder of this scrutiny:

\begin{abstract}
"The actual dissection process will be recorded. We've got a window looking into room one. So a person on the outside can be watching a video of the dissection and can also validate the whole process. And all the videos will be kept. So if afterwards a patient has been transplanted and, for example, maybe the graft isn't working or the graft has rejected, we can show the video to our colleagues in, for example, France or somewhere and we can confirm that the dissection was correctly done."
\end{abstract}

The cameras positioned on the dissection process have a dual purpose. In the first instance it was explained that they are displayed to capture images that will be used as a teaching aid in order to educate others on how best to go about performing this novel and pioneering technique. However there is a suggestion of a covert process of surveillance creep (Marx 1988). In the second instance, as is revealed in the extract by Dr. Leonard, it is a technology that objectively records and, hopefully (for the sake of Headlab at least), verifies the procedure ${ }^{6}$.

\footnotetext{
${ }^{6}$ Although some at Headlab suggest that this is not essential for GMP compliance, videoing the dissection has become firmly etched in to the laboratories SOPs. This flexible interpretation of the standard has some similarity with the work of Hoeyer who demonstrates how EU standards become transfigured as they are locally interpreted by scientists during implementation (cf. Birk and Hoeyer 2007; Hoeyer 2010).
} 
Latour \& Woolgar (1979) demonstrated how scientists working in a protein laboratory were required to re-trace their practices when they discovered anomalous findings. In a similar way, Headlab will have access to stored video evidence to reexamine their methods if a cell graft is rejected during clinical transplantation. One of the differences, however, between Latour's laboratory ethnography and this study is that Headlab are conducting translational research (Wainwright et al. 2009). This dissimilarity demonstrated most palpably in the way Headlab's research will have direct impacts on patients mean that researchers working at Headlab are positioned as potentially culpable if procedures are found not to have been properly adhered to ${ }^{7}$. Accordingly, the monitoring technologies do not just re-classify and reinforce scientists as potentially dangerous individuals, but are also a way for the same scientists to provide 'real-time', rather than re-enacted, evidence that they followed the correct written agreed procedures.

A further change in daily work practice is the adoption of ritual-like routines performed by GMP workers. The gowning procedure involved when suiting-up into the appropriate laboratory costumes has some elements of a liminal ceremony, as actors pass across spatial and symbolic boundaries. At first glance it may appear that the transformation into colloquially known 'bunny suits' is a type of ceremonial enactment marked by special clothing for important people who are permitted into the sacred space, and which differentiates them from others. But the wider cultural framework of this transformation also constructs the actors as constrained and restricted. The symbolic boundaries not only restrict entry to the space, but also demarcate scientists' activities, leaving them constrained in their creative actions and scientific independence. The

\footnotetext{
${ }^{7}$ In February 2009, BBC ran a story raising questions about the safety of foetal stem cells when a young Russian boy started to develop tumours after surgery (BBC 2008).
} 
process is analogous to the mortification rituals of total institutions (Goffman 1961) or even degradation ceremonies (Garfinkel 1956; Housley 2009). These ceremonial experiences transform social actors from creative scientists and professional technicians into standardized functionaries, performing highly regulated sets of actions. Indeed, GMP constructs the actions of GMP scientists as best practice procedures. In the process, the scientific laboratory is transformed into a kind of total institution or panopticon (Foucault 1975) in which its personnel are subject to scrutiny, measurement and monitoring. The following is an extract from an interview with Dr. Leonard who was asked whether they use such best practice procedures in all the work they conduct:

\section{I: When you have the kind of GMP training, do you get a certificate for that?}

Dr. Leonard: Yes.

\section{I: And so was that useful?}

Dr. Leonard: Yes. It was a day long with the consultant, and he came down and we spent a day going through the whole course with him and then we had to take an exam at the end of it...It was all about issues of a clean room, how to maintain a clean room, how to clean a clean room and how to gown up and all these kind of issues, and really just understanding the microbiology really as well as everything else. So yeah, it was useful.

\section{I: And are you using any of those practices in other parts of your work now?}


Dr. Leonard: No. It is far too rigorous.

It is evident from this account that GMP can be uncomfortably burdensome for bench scientists, and it is revealing that Headlab have not translated the sterility practices that they have learned during GMP training in to other areas of the laboratory. The only occasions that Headlab will incorporate such measures are when it is compulsory to do so. The encumbrance of GMP represents an environment where scientific work in cell transplantation is too risky to be trusted to regulate itself (Kent \& Faulkner 2002). Therefore, a new set of work practices are required in order to demonstrate that such work is being controlled and not allowed to run wild. In this sense, the gowning ritual performed by Headlab members can be perceived as a type of ceremonial performance, in which it is made known in no uncertain terms that the scientists are part of a wider regulatory procedure where their actions will be centrally controlled, and that any medical breakthroughs will be part of a wider collaborative approach to such trials. The uniform is one representation that they are being regulated from outside and displays them as individuals who can contaminate tissue.

Regimes of visible accountability, such as the one we have been describing here, clearly have elements of procedural display (Bloome, Puro and Theodorou 1989; Atkinson and Delamont 1990). That is, they are an array of performances that are simultaneously functional and ceremonial. They are, partly, enacted in order to fulfill an obligation that they are seen to be done and, to that extent, are self-justifying forms of activity. There is then no incompatibility between the functional and the ceremonial. There are, of course, good scientific and clinical reasons for the sterility of laboratories and cell banks such as the reduction of infection (Unger et al. 2008). But, the control and 
management of contamination also invites reflection on the symbolic management of pollution. As Douglas (1966) demonstrated, matter out of place, as 'dirt', elicits ritualised forms of management, through the cultural construction of symbolic membranes that maintain the purity of categories. More fundamentally, the practical management of laboratory life can take on a ritual form. As Schwartzman (1987) suggests, routine organisational activities can take on the characteristics of what Victor Turner describes as 'social dramas' (Turner 1974).

Indeed it is normal for functional, practical actions to become ritualised. A classic example is reflected in the work of Julius Roth (1957). Based on an ethnography of a TB hospital, Roth documented the varieties of action related to the control of contagion. Clearly with a highly infectious condition like TB, hospital-staff have every practical motivation to ensure that risks of infection are minimised, and that steps are taken to maintain boundaries between sterile and potentially infectious materials, objects and places. But as Roth also demonstrates, these procedures take on a ritual-like character. Observed for their own sake, their actual performance does not necessarily conform to the scientific or clinical imperatives of infection control. In other words, there is a ceremonial order to the laboratory (cf. Strong 1979 on the ceremonial order of the clinic) that parallels what Fox (1992) has called the circuits of hygiene in the hospital. Quality assurance checks such as GMP then have consequences on the visualization, explication and accountabilities of practices and processes in the laboratory. While, the physical space of the laboratory, the regulation of movements within it, and the maintenance of boundaries all shape its ceremonial order. 


\section{Concealing and Revealing Identities}

We have already established that the University's Security and Estates will have no access to the GMP suite. One of the reasons for this is that Headlab must keep a detailed record of who has entered in the room in order that they can re-trace every individual's movement if required. Therefore, and mirroring the swipe card system they have in place for those entering the building, Headlab have built a similar apparatus to monitor the flow of personnel into and out of the facility. Here we see the surveillance of mobility. Dr. Cowan explains:

"We realised that we needed to be able to prove who had been in and out of the suite. And we needed to prove that nobody had actually entered the suite overnight. Say we've set tissue up and we've left it in there overnight, we need to be able to prove no-one's been in there. So what we did was - we bought an independent version of the university's access card system, which is unique to this lab and is controlled from, again, my office; from a PC in here. And we've issued cards only to people that are qualified to work in the lab. And that allows us to monitor what goes in and out. The software records all access to the suite so we know who's gone in and out... It's been made very clear to the users that cards are not to leave the building either because we don't want those cards dropped outside and handed on to somebody else. So it's been made very clear to people that those cards have got to be kept safe...It means there is no access for security or estates or anybody else. None of them have access."

Combining the procedure of suiting up in the appropriate clothing with the access card system, it is evident that the card mechanism becomes the technology that 
acknowledges an actor's presence in the suite. It is even plausible to suggest that by covering their bodies from head to toe in uniform, individuals in the group only become identifiable by the swipe card - a secondary object that represents a record that they were in the room at a particular time. Accordingly, one SOP compels them to conceal both their biological-material and subjective-symbolical identity (by wearing a fully-clothed Tyvek suit). While a secondary SOP forces them to reveal their individual identity (the card system). Moreover, the card system produces a 'clocking in' procedure (Thompson 1967; Zureik 2003) further changing the work practices at Headlab, while the card itself is a technological symbol that divides laboratory members.

The swipe-card procedure is also a good example of a local implementation of a wider global regulatory process. Dr. Cowan gives details of the ways in which they invest in a local institutional system to control the flow of personnel in and out of the facility, controlled from within their office. Once more, if implemented, this would change the relationships within the group, since at least one Headlab member will be primed with the task of keeping tabs of the other members who enter. Here, power is localised and controlled from within the group as the SOP places the responsibility on the cellular scientists themselves, incorporating them as an active participant in their own selfsurveillance (Swage 2000). Similar issues regarding the local implementation of wider surveillance strategies are also apparent in the description of the next monitoring technology.

\section{Surfacing Bits of Previously Hidden Variables}


Further monitoring technologies that are being put into operation in the GMP suite are a set of air pressure barometers. This technology is not intended to surveil the actions of the scientists nor ensure that only suitably qualified members enter the suite. Rather, they are put in place to monitor the sterility of the environment in which such procedures are performed. Positioned in the suite, the instruments bring to the surface previously hidden variables. In the previous non-GMP environment where initial transplant trials began, air pressure was not controlled and not required to be controlled. However, in a similar way to how the products of science have been made visible (genes; stem cells) through developments in technologies, in this setting so have variables of control. Such processes of visibility and accountability translate the local, craft practices of laboratory and clinical work - often tacitly performed and transmitted - into explicit, global forms of knowledge production and regulation. Therefore, air pressure measurement has emerged as an objective way to verify the environment in which scientists work, and is used to categorise an uncontrolled environment as impure, unclean and untrustworthy. Air pressure has been brought to the surface to become an 'uncertain' substance that needs to be measured and controlled by scientists, and thus turns an 'unaffected' environment into an 'artificially clean' one. It would appear then that perceived risk is heightened under GMP conditions since the facility is reinforced with contingency procedures not implemented previously. More generally, the purity of air becomes an alterable variable, and impure air a foreign enemy attempting to invade.

Originally, Headlab installed barometer gauges on the outside of the suite with an analogue needle recording the pressure inside the rooms. This was before independent 
consultants evaluated this set up and proposed that it be altered. Dr. Cowan describes what happened:

"So when estates built the room, they gave us the barometers on the wall outside, which was fine, until our external validators came in and tested the pressure in the room with independent equipment and said hang on, this isn't actually reading what your barometers say. Then we thought what would happen if someone began tampering with it using a screwdriver...So we discussed getting access to the university's BEMS system, their environmental monitoring system which monitors the entire university campus, temperatures, pressures, whatever they want to do with it. So we bought a copy of BEMS and I have it loaded on my PC and it means that I can record information from the rooms. It can't be fiddled with. We can see what's going on. It has given us the added bonus that I also now has alarms built in here on the floor."

This extract raises three points. The first is the importance placed on an accurate reading of pressure. The external consultants impressed on Headlab that a more exact and more user-friendly system of monitoring as provided by calibrated, computerised pressure gauges was required. This precision is part of a wider meticulousness recital that Headlab have to perform under GMP conditions. It is a degree of accuracy though that Mackenzie (1990) challenges in his work on scud missiles in which he demonstrates how technical faults such as missile accuracy might be disputed ${ }^{8}$.

Second, the display of digital barometers is partly the result of the group being accountable for the actions of perceived 'outsiders'. What was discovered by the external

\footnotetext{
${ }^{8}$ Further consistency with Mackenzie (1990) is apparent in the ways in which he argues that technological change is simultaneously economic, political, organisational, cultural and legal change.
} 
examination process is that Headlab's initial barometers were open to sabotage from outsiders. There was potential for 'outsiders' to use screwdrivers to alter the readings of the barometers from the outside of the suite. The choice to revert to the BEMS system is a clear indication that Headlab are internalising as many foreseeable variables as possible, and once more we observe a divide founded on notions of 'insiders' and 'outsiders'.

The third feature of the extract that is significant from the extract is the interpretive local flexibility of a global regulation. As way of making obvious that the air pressure is regulated inside the suite, Headlab have decided to employ a local university system (BEMS). This technology may not be so readily available to other institutions who might decide to employ alternative systems of measurement. This is another example of the localness of monitoring practices. Although regulatory structures are (trans-)national, initial responsibility for regulatory control comes from inside the group; in this case by a nominated member. Processes of GMP Quality Assurance are then as much about internal surveillance and the control of internal laboratory procedures and laboratory personal as anything else (Leslie 2010).

\section{Surveillance Sorting and Shaping}

We have read how Headlab have to perform acts of meticulousness under GMP conditions in order to keep their space in check. This heightened scrutiny draws attention to the responsibility and accountability of any bad practice and firmly positions it in the hands of the Headlab group. Nevertheless, the traditional idea of translational research, taking research from 'bench to bedside', implies that basic research conducted in the 
laboratory will have direct impacts by producing breakthrough therapies (Wainwright $e t$ al. 2006). Within Headlab, once the GMP facility is built and accredited, research into the clinical possibilities of primary cell tissue are predicted to have speedy applications for early onset HD patients. It is imagined that biomedical scientists at Headlab will continue to work with clinical scientists at the HD clinic and brain surgeons at the local hospital to implant the cellular graft into suitably chosen patients. For this to function, primary foetal tissue is transferred from the hospital to the GMP facility at Headlab ${ }^{9}$, potential HD patients are enrolled from the HD clinic and, once the tissue has been treated, patients will be implanted in the hospital. It is clear therefore that we have three separate sites involved in the GMP process - Headlab, the HD clinic and the hospital. It would also appear, however, that the monitoring and control of the GMP process is highest, and restrictions on sterility tightest, when the tissue is in hands of Headlab. This process is not lost on Headlab members. When asked about the role of the local hospital, Dr. Leonard responded:

"They are part of our clinical license as well, but we have no control over what their theatre's like. That's what we all think is really funny, because we're getting it from a hospital, which isn't exactly the cleanest place on the planet, and we're handling it as if it's the most precious thing in the world and we're keeping it as sterile as we possibly can then we're handing it back to a hospital."

Dr. Leonard's reply suggests that there is a hierarchy to the 'degrees of surveillance' within GMP regulation and it is within the confines of the facility that we

\footnotetext{
${ }^{9}$ Similar documentation of the route aborted foetus tissue take can be found in Kent (2008).
} 
observe the greatest surveillance of research action. Despite the hospital and the HD clinic being part of the clinical license, it is only within Headlab where sterility issues are scrutinised to such a degree. Despite best practice guidelines being upheld outside the laboratory, they are not at the apparent same level of sanitation and inspection as the GMP facility. This 'surveillance sort' (Lyon 2003) could be part of wider mistrust in scientific practice where scientists are perceived as risk-takers, or a product of the institution of science attempting to be more transparent. The traditional concealment of scientific practice is one that Headlab fully acknowledge and attempt to rectify by holding patient support group open days within the laboratory. It is also a feature of the performative architecture of scientific buildings (Stephens et al. 2008; Thrift 2006).

Although the work of medical procedures within hospitals is partitioned, sections of the building are open to the public, families and patients. The work of scientists however is often cordoned off within the inner sanctuary of laboratories, which may not have a public face. GMP attempts to compensate this concealment with heavy documentation of every procedure performed. The documentation of every detail and the garnering of information is part of a wider documentary culture found in biomedical practice (Stephens et al. 2008). For the purposes of Headlab, the rationale behind such an approach is, once more, the ability to trace the actions of the group. Dr. Leonard comments on this surveillance practice:

"GMP requires that the tissue is handled under defined conditions, both in terms of the environment, in terms of the protocols for the steps of the handling and in terms of the documentation for traceability. We simply have to document everything... The documentation provides traceability for demonstration compliant with the HTA, for 
ethical issues and for the consequence of an adverse event; you can go back and see where it came from ultimately".

Documentation is an example of how regulatory structures are reinforced through surveillance technologies even when no inspectors are present, extending the reach of surveillance (Rose \& Miller 1992) and problematizing an event in order to make it visible. It is worth drawing attention to the use of such documentation. As is obvious from the explanation, documentation provides testament and description of the group's actions. Once recorded, SOPs are etched in history as custom and conduct performed by Headlab members, inscribing the group's interpretation of the global regulatory structure (Stephens et al. 2008). Previous to GMP conditions, such scrutiny of individual actions may have remained invisible and unrecorded to those outside the group. But the current audit explosion (Power 1997) or audit culture (Strathern 2000b) as a source of internal governance found in other places of work has now extended to the scientific laboratory, and the documentation of all procedures shapes a wider audience - the regulators.

The rationale behind Dr. Leonard's reasoning for the requirement of documentation is so Headlab can re-trace their steps if the transplantation does not work as intended. Once more, as is the case with Latour \& Woolgar's (1979) research, retracing will only occur if things go wrong, implying that most documentation will remain stored away if trials have progressed smoothly. This is a further example of the surfacing of selected practices and has some similarities with the 'chains of custody' discussed by Lynch \& McNally (2005) in relation to DNA profiling in court cases.

Chains of custody link crime scenes to samples of DNA stored in forensic laboratories, making suspects accountable and evidence legitimate. Lynch and McNally 
examine the case of a murder conviction where the defence attorney raised the issue that some of the signatures on the sample forms were photocopied instead of hand-signed. These practices uncover what would usually be accepted as an unproblematic link in the chain of custody from the laboratory bench to the courtroom. Various actors, practices, and accountability structures were brought to the surface where otherwise they would have remained hidden and taken for granted, subsumed in a bureaucratised sample form. Over time, GMP SOPs will fill the same function as the sample DNA form linking the laboratory to external tissue regulators. Moreover, in this paper we have made explicit as they happen - the local work practices necessary to narrow the gap between the externally imposed regulatory documents and local practical 'do-able' regulation (Stephens et al. 2008). Indeed, documentation employed by users and implementers of regulatory frameworks not only shape regulations in practice but actually make them possible: documentation is a significant part of the GMP process (Rose 1999).

Furthermore the same unfolding process described by Lynch \& McNally in the DNA case may occur if the situation arises that the graft implanted into a Huntington's patient has not been accepted smoothly. Then the chain of papers associated with GMP will be unfurled to reveal the practices of the scientists at Headlab, in so doing multiplying the points at which malpractice might have occurred.

It would appear then that stringent documentation in the laboratory changes scientists' relationships with one another and with those outside the laboratory. It makes researchers think beyond the scientific laboratory and the clinical trial and into wider societal processes of actions and reactions. As Leslie (2010) argues GMP extends further 
and wider than simply scientific procedures because you can erase laboratory experiments but you can't destroy GMP documentation.

Despite understanding the reasons for chronicling and storing every formal action and interaction, members of the group believe it is unmanageable, burdensome and excessive. On this, Dr. Leonard:

“They want us to keep records for 30 years. Hospitals don't even keep records for 30 years. Where are we supposed to store 30 years' worth of documentation? That's just crazy really. That's only one example, and some of it is just not workable, but people have put these regulations down and we've got to make them workable...It's a nightmare and a very hard working environment"

The uncomfortable environment that is portrayed here is a further example of how the monitoring of cellular transplantation is tightest within the sphere of Headlab's activities, and how 'surveillance is being designed in to the flow of everyday [scientific] life' (Rose, 1999: 274). In the extract, Dr. Leonard compares the new monitoring procedures to the ways in which hospitals are routinely required to store documentation about their practices. In arguing that not even hospitals store documentation for 30 years, she is not only stating that they simply do not have the provision to store the documents, but is also suggesting that it is unreasonable for the group to be assessed in the same way as hospitals. In comparing the length of time Headlab are required to archive documents with the length of time hospitals are required, the group essentially recognise that they are being categorised in the same field as other larger medical institutions that are the site of severe patient complications and mortalities. This is a further sign that current 
translational research is entering a new biomedical terrain. It is important to note, however, that Headlab are required to store their documentation longer. Clinical trials are no longer the vehicle for escape from politics, but have become the medium of political engagement with the biomedical terrain (Brown 2005). Important to this comparison is that the extensive period of storage implies that the group are culpable for adverse effects many years after the transplantation ${ }^{10}$. Time then becomes a further factor in the labelling of scientists as potentially dangerous individuals as cellular scientists are viewed as being 'before their time'. Indeed, circuits of regulatory control are extending both spatially and temporally (Dandeker 2007) as the unknown future consequences of today's actions are risk-evaluated.

\section{Discussion}

This paper has examined and discussed the evolving work practices of scientists involved in innovative biomedical procedures. Just as new technologies and new instruments have been developed to advance biomedical research, so technologies have been developed to monitor the practices and implementations of such procedures. What we have discussed then is the Janus-faced component of technology. Developments in information and recording technology simultaneously create and monitor a more sterile, less risky, laboratory. Scientists and technicians can therefore control for variables that were previously invisible or were not measurable. These technologies of surveillance regulate space, action and movement within laboratory settings. But, they also constrain the scientists themselves. In fact the growth of monitoring technologies and the execution of

\footnotetext{
${ }^{10}$ This may impact upon the prioritisation and allocation of resources and the coordination of the work conducted at the laboratory, slowing down the pace of research (cf. Georgiou, Westbrook and Braithwaite 2011 for the impact e-technologies has on the temporal landscape of the pathology hospital).
} 
ceremonial procedures can potentially transform scientists' identities. Along with the tissue, scientists themselves become risky and dangerous actors that require restraint. Even though Headlab help to pioneer new methodologies and new therapies, and despite the fact that they play a significant role in the construction of their own regulatory procedures (Authors), their work is being scrutinised and constrained. It is monitored in both conspicuous and subtle ways. Conspicuous surveillance is noticeable through the creation and placement of such visual monitoring technologies as cameras and barometers. This is paralleled in a more subtle way, through the monitoring of scientists' actions (Swage 2000). Regulatory frames are transformed and realised through disciplinary regimes in the laboratory.

In another paper we have developed a theoretical resource for understanding the development of regulatory practice at Headlab - the regulatory regress (Stephens et al. n.d). We demonstrate the significant part that Headlab plays in creating the regulatory procedures that monitor their own actions. Laboratories and regulatory bodies are engaged in mutual influence. It is not a case of external surveillance operating in one direction only. Laboratories and regulators both have to make practical judgments as to the intention of regulatory protocols, and the adequacy of compliance with them. Laboratory work therefore develops an additional dimension. New SOPs mean that scientists are required to become self-documenting in ways that are more far-reaching than traditional record-keeping (such as laboratory notebooks).

The construction of such standards and procedures of compliance implies a transformation in scientific work. The work of the laboratory thus accommodates the tasks of accountability itself. Local laboratory work is transmuted not just into scientific 
findings, published papers, and other scientific outcomes ${ }^{11}$. It is also translated into representations of the work itself. Hence, there arises a series of imperatives that laboratory scientists must accommodate: they must translate everyday work techniques into artefacts that reflexively construct and legitimate those techniques themselves. But, where once laboratory work depended to a large degree on 'trust', newer modes of regulation impose new layers of mutual surveillance. The laboratory itself is thus rendered visibly accountable through techniques of inspection, documentation and visibility. Therefore laboratories are drawn into working practices that mirror the wider cultural contexts of reflexive modernisation and pervasive accountability.

The global geography of scientific collaborations is then mirrored by the local geography of the laboratory itself: its physical setting, movements and circulation within it, where the passage of persons and materials (such as tissue samples or cells) must themselves be monitored and explicated. To this end there has been a changing relationship between the laboratory bench, the State, and global agencies of regulation (Flynn 2002). There are now multiple locations of control split between various organisations. Circuits of biological materials are tracked by different types of surveillance machinery that endeavour to monitor new translational techniques.

The achievement of GMP accreditation is but one example of the current imperative towards reflexive accountability. The stringent requirements for GMP throw this more general process into relief. The prevention of harm and the preservation of patient safety are of utmost concern. The architecture of the laboratory space, the

\footnotetext{
${ }^{11}$ On commenting on the tensions between the local and the global, Star (1985: 1989) argues that scientists are more likely to define real scientific practice as moving claims from local uncertainties to global certainties and that the management of local uncertainties particularly those involving administrative-type work is perceived as non science.
} 
functional and symbolic boundaries that are imposed, the performative display of compliance, and the presence of monitoring equipment all create a disciplinary regime that regulates scientists' bodies and their movements. Laboratories are thus transformed into sites of potentially dangerous identities. For example, recent technologies to support collaborative scientific work have sought, in various ways, to enhance individuals' awareness of another actor's activities (Luff, Heath \& Jirotka 2000). This has meant that biomedical science is now pursued in an environment of heightened awareness of one's self and of others, and if laboratory work was once conducted and communicated with a strong element of trust and tacit knowledge, today new tokens of trust are required as scientists are increasingly rendered visible to the scrutiny of others. Visibility is enhanced through these technologies of inspection and surveillance, by increased volumes of selfdocumentation, and by the imposition of regulatory protocols. These all help to transform what was once implicit in the working practices of trusted professionals into explicitly accountable practices. Those practices are constructed, therefore, as inherently untrustworthy and in need of legitimation. Together, these procedures represent a technology of trust.

Of course, trust is a fundamental pre-requisite of relations between scientists and between scientific organisations. Laboratories engage in complex networks of collaboration which, even though potentially coloured by elements of competition, must rest fundamentally on a degree of interpersonal trust. Such trust is often tempered with caution, insofar as trust always has the potential to create risks, and research scientists who entrust others with data and materials can run the risk of abuse. Increasingly, however, interpersonal trust between scientists is supplemented by, and translated into, 
system-based trust, based on protocols of mutual surveillance, as exemplified in the work of Headlab scientists. This is a form of what Cambrosio. Keating, Schlich and Weisz (2006) refer to as 'regulatory objectivity'. That is, an array of technologies of evidence that includes forms of measurement, standardisation, guarantees of purity, and regulatory practices. The process, Cambosio and his co-authors argue, mirrors Robelet's description of the decline of professional regulation and a corresponding increase in industrial models of regulation (Robelet 1999). In the clinical context, Moreira, May and Bond (2009) argue that procedures of regulatory objectivity underpin collaborative, crossinstitutional work and knowledge-production.

Computers and other technologies increase the capacity and scope of surveillance, regulating the flows both in and out of a fixed remote location and reinforcing surveillance as a feature of large scale organisations and global enterprises (Zuriek 2003). With GMP, new monitoring technologies therefore create new 'contours of surveillance'. These new surveillance technologies are part of a wider audit culture (Power 1997) and may be used as evidence by the researchers to demonstrate their competence. Indeed, if transplantation is not successful, Headlab may refer to archived documentation, recorded tapes and/or pressure recordings to demonstrate they followed the criteria set down by the guidelines. If it is found that they followed correct procedures this could deflect criticism. Thus, the 'objectivity' provided by independent technologies can constrain scientists, but can also absolve them from blame.

\section{Acknowledgements}


The support of the ESRC is gratefully acknowledged. This work is part of the research programme of the ESRC Genomics Network at Cesagen.

\section{References}

Appelbe, G.E. (2005). From Arsenic to Thalidomide: A Brief History of Medicine Safety. In S.C. Anderson (eds.), Making Medicines: A Brief History of Pharmacy and Pharmaceuticals. London: Pharmaceutical Press, 243-260.

Atkinson, P. \& Delamont, S. (1990). Procedural Display and the Authenticity of Classroom Activity'. Curriculum Inquiry 20,1: 63-69.

Atkinson, P., Batchelor, C. \& Parsons, E. (1998). Trajectories of Collaboration and Competition in a Medical Discovery. Science, Technology and Human Values 28, 3: 259-284.

Bartlett, A. \& Arribas-Ayllon, M. (2009). What is Big about the Science of Psychiatric Genetics? The Society for the Social Studies of Science 2009 Annual Meeting. October $28^{\text {th }}-31^{\text {st }}$, Washington DC.

Bloome, D., Puro, P. \& Thodorous, E. (1989). Procedural Display and Classroom Lessons. Curriculum Inquiry, 19, 3: 265-291.

Birk, S.O. and Hoeyer, K. (2010) The Effect of the EU Tissues and Cells Directive on Bone Banking in Denmark: A Case Study. Cell Tissue Bank. 11: 225-232.

British Broadcasting Cooperation (2009). 'Stem Cell Cure Boy gets Tumour', 18 February, URL (accessed September 2009) http://news.bbc.co.uk/1/hi/health/7894486.stm 
Brown, N. \& Webster, A. (2004). New Medical Technologies and Society: Reordering Life. Cambridge: Polity Press.

Brown, N. (2005). Shifting Tenses - From Regimes of Truth to Regimes of Hope? Configurations, 13(3), 331-355.

Burri, R.V. \& Dumit, J. (2008). Social Studies of Scientific Imaging and Visualisation. In E.J. Hackett, O. Amsterdamska, M. Lynch and J. Wajcman (eds.), The Handbook of Science and Technology Studies. Cambridge MA: MIT Press, 297-317.

Cambrosio, A., Keating, P., Schlich, T. and Weisz, G. (2006) Regulatory objectivity and the generation and management of evidence in medicine, Social Science and Medicine, 63, 1: 189-199.

Crary, J. (1992). Techniques of the Observer: On Vision and Modernity in the Nineteenth Century. Cambridge MA: MIT Press.

da Solla Price, D.J. (1965). Little Science, Big Science. New York and London: Columbia University Press.

Dandeker, C. (2007). Surveillance: Basic Concepts and Dimensions. In S.P. Hier and J. Greenberg (eds.), The Surveillance Studies Reader. Maidenhead: Open University Press, 39-51.

Douglas, M. (1966). Purity and Danger. London: Routledge and Kegan Paul.

Dumit, J. (2004). Picturing Personhood: Brain Scans and Biomedical Identity. Princeton, N.J: Princeton University Press.

Faulkner A, Kent J, Geesink I \& Fitzpatrick D. (2006). Purity and the Dangers of Regenerative Medicine: Regulatory Innovation of Human Tissue Engineered Technology. Social Science and Medicine, 63, 2277-88. 
Finkler, K. (2000). Experiencing the New Genetics: Family and Kinship on the Medical Frontier. Philadelphia: University of Pennsylvania Press.

Flynn, R. (2002). Clinical Governance and Governmentality. Health, Risk and Society, 4(2), 155-173,

Foucault, M. (1975). Discipline and Punish: The Birth of the Prison. New York: Random House.

Fox, N. (1992). The Social Meaning of Surgery. Milton Keynes: Open University Press.

Franklin, S. (1995). Science as Culture, Cultures of Science, Annual Review of Anthropology, 24: 163-84.

Franklin, S. (2001). Culturing Biology: Cell Lines for the New Millennium, Health. 5(3), $335-354$

Fyfe, G. and Law, J. (eds) (1988) Picturing Power: Visual Depiction and Social Relations, Sociological Review Monograph 35. London: Routledge

Galison, Peter (1997). Image and Logic: A Material Culture of Microphysics. Chicago: University of Chicago Press.

Garfinkel, H. (1956). Conditions of Successful Degradation Ceremonies'. American Journal of Sociology. 61: 420-424.

Georgiou, A., Westbrook, J.I, Braithwaite, J. (2011) Time Matters - A Theoretical and Empirical Examination of the Temporal Landscape of a Hospital Pathology Service and the Impact of E-Health. Social Science and Medicine 72: 1603 -1610.

Goffman, E. (1961). Asylums: Essays on the Social Situation of Mental Patients and Other Inmates. New York: Doubleday. 
Haraway, D.J. (1991). Simians, Cyborgs and Women: The Reinvention of Nature. London: Free Association.

Hindmarsh, R. (2008). Edging Towards Bioutopia: A New Politics of Reordering Life and The Democratic Challenge. Crawley: University of Western Australia Press.

Hoeyer, K. (2010). An Anthropological Analysis of European Union (EU) Health Governance as Biopolitics: The Case of the EU Tissues and Cells Directive. Social Science and Medicine, 70, 1867-1873.

Housley, W. (2009). Interaction, Discourse and the Subject. Subjectivity, 26, 69-86.

Kater, L. (2007). The UK Stem Bank: Creating Safe Stem Cell Lines and Public Support?' In P. Glasner, P. Atkinson and H. Greenslade (eds.) New Genetics, New Social Formations. New York: Routledge, 37-68.

Keller, E.F. (2000). The Century of the Gene. Cambridge, MA: Harvard University Press.

Kent, J. \& Faulkner, A. (2002). Regulating Human Implant Technologies in Europe Understanding the New Era in Medical Device Regulation. Health, Risk and Society, 4(2), 189-209.

Kent, J. (2008). The Fetal Tissue Economy: From the Abortion Clinic to the Stem Cell Laboratory. Social Science \& Medicine, 67, 1747-1756.

Latour, B. \& Woolgar, S. (1979). Laboratory Life: The Construction of Scientific Facts. Princeton, NJ: Princeton University Press.

Leslie, M. (2010) Quality Assured Science: Manageralism in Forensic Biology. Science Technology and Human Values, 35, 283-306.

Lewis, J. D. and Weigert, A. (1985). Trust as a Social Reality, Social Forces, 63, 4: $967-$ 985. 
Luff, P., Heath, C. \& Jirotka, M. (2000). Surveying the Scene: Technologies for Everyday Awareness and Monitoring in Control Rooms. Interacting with Computers, 13(2), 193-228.

Lynch, M. (1985). Discipline and the Material Form of Images: An Analysis of Scientific Visibility, Social Studies of Science, 15: 37-66.

Lynch, M. \& McNally, R. (2005). Chains of Custody: Visualization, Representation and Accountability in the Processing of Forensic DNA Evidence, Communication and Cognition, 38(3-4), 297-318.

Lynch, M. \& Woolgar, S. (eds) (1990) Representation in Scientific Practice. Cambridge Mass: MIT Press.

Lyon, D. (2003). Surveillance as Social Sorting: Computer Codes and Mobile Bodies. In D. Lyon (eds.) Surveillance as Social Sorting. London: Routledge, 13-30.

Lyon, D. (2007). Surveillance Studies an Overview. Cambridge: Polity Press.

MacKenzie, D. (1990). Inventing Accuracy: A Historical Sociology of Nuclear Missile Guidance. Cambridge, MA: MIT Press.

Marx, G.T. (1988). Undercover: Police Surveillance in America. Berkeley: University of California Press.

Moreira, T. May, C. and Bond, J. (2009) Regulatory objectivity in action: Mild cognitive impairment and the collective production of uncertainty, Social Studies of Science, 39, 5: 665-690.

Penders, B. (2008). From Seeking Heath to Finding Healths: The Politics of Large-Scale Cooperation in Nutrition Science. Maastricht: University of Maastricht Press.

Power, M. (1997). The Audit Society. Oxford: Oxford University Press. 
Robelet, M (1999) Les médecins placés sous observation: Mobilisation autour du développement dde l'évaluation médicale en France, Politix, 46: 71-97.

Rose, N. \& Miller, P. (1992). Political Power Beyond the State: Problematics of Governmentality. British Journal of Sociology, 43, 173-205.

Rose, N. (1999). Powers of Freedom. Cambridge: Cambridge University Press.

Roth, Julius (1957). Ritual and Magic in the Control of Contagion, American Sociological Review, 22(3): 310-314.

Saunders, B. F. (2008). CT Suite: The Work of Diagnosis in the Age of Noninvasive Cutting. Durham NC: Duke University Press.

Schwartzman, H. B. (1987). The Significance of Meetings in an American Health Center, American Ethnologist, 14: 271-94

Star, S-L. (1985). Scientific Work and Uncertainty. Social Studies of Science, 15(3), 391427.

Star, S-L. (1989). Regions of the Mind. Brain Research and the Goal of Scientific Certainty. Stanford, CA: Stanford University Press.

Stephens, N. Atkinson, P. \& Glasner, P. (2008). The UK Stem Cell Bank as Performative Architecture. New Genetics and Society, 27, 87-99.

Stephens, N., Lewis, J. and Atkinson, P. (n.d.) Closing the regulatory regress: GMP accreditation in stem cell laboratories. Unpublished Manuscript. Cardiff University: School of Social Sciences.

Strathern, M. (2000a). The Tyranny of Transparency. British Educational Research Journal, 26: 309-21.

Strathern, M. (ed.) (2000b). Audit Cultures: Anthropological Studies in Accountability, Ethics and the Academy. New York: Routledge. 
Strong, P.M. (1979). The Ceremonial Order of the Clinic: Parents, Doctors and Medical Bureaucracies. London: Routledge and Kegan Paul.

Swage, T. (2000). Clinical Governance in Health Care Practice. Oxford: ButterworthHeinemann.

Thompson, E.P. (1967). Time, Work-Discipline, and Industrial Capitalism. Past and Present, 38(1), 56-97.

Thrift, N. (2006). Re-inventing Invention: New Tendencies in Capitalist Commodification. Economy and Society, 35(2), 279-306.

Tsoukas, H. (1997). The Tyranny of Light: The Temptations and Paradoxes of the Information Society. Futures 29: 827-43.

Turner, V. (1974) Dramas, Fields and Metaphors. Ithaca NY: Cornell University Press.

Unger, C., Skottman, H., Blomberg, P., Dilber, M. \& Hovatta, O. (2008). Good Manufacturing Practice and Clinical Grade Human Embryonic Stem Cells Lines. Human Molecular Genetics 17(1): R48-53.

Van Dijck, J. (2005). The Transparent Body: A Cultural Analysis of Medical Imaging. Seattle: University of Washington Press.

Wainwright, S., Williams, C., Michael, M. \& Cribb, A. (2009). Stem Cells, Translational Research and the Sociology of Science. In P. Atkinson, P. Glasner and M. Locke (eds) Handbook of Genetics and Society: Mapping the New Genomic Era. New York: Routledge, 41-58.

Wainwright, S., Williams, C., Michael, M., Farsides, B. \& Cribb, A. (2006). From Bench to Bedside? Biomedical Scientists' Expectations of Stem Cell Science as a Future Therapy for Diabetes. New Genetics and Society, 26, 251-268. 
Wilson-Kovacs, D.M., Weber, S. \& Hauskeller, C. (2010). 'Stem Cells Clinical Trials for Cardiac Repair: Regulation as Practical Accomplishment'. Sociology of Health and Illness, 32(1), 89-105.

Zureik, E. (2003). Theorizing Surveillance: The Case of the Workplace. In D. Lyon (ed.) Surveillance as Social Sorting. London: Routledge, 31-56. 